補緅誌, J Jpn Prosthodont Soc, 43：857〜866, 1999.

\title{
原著論文
}

\section{リン酸塩系埋没材を用いた純チタン鋳造床 ーコーティング法による反応層の改善一}

\author{
森口愛 小正 裕* 柿本 和俊* 権田 悦通*
Pure Titanium Denture Base Cast Using Phosphate-Bonded Investment -Improvement of Reactive Layer by Coating Method-

\author{
Ai Moriguchi, Yutaka Komasa*, Kazutoshi Kakimoto* and Yoshimichi Gonda*
}

\begin{abstract}
It was attempted to coat the refractory models by zirconia to improve a reactive layer of the pure titanium denture base cast using phosphate-bonded investment and to compare with a usual investing method.

When the coating refractory models were used, the small residual investment on the casting plate removing from the mold was observed.

The surface hardness of the castings prepared with TAIVEST was hardly different between the two samples. However, the surface hardness of the castings prepared with T-INVEST C \& B was slightly greater control samples on the casting surface to a depth of about $30 \mu \mathrm{m}$, but there was little difference between the samples for the depth.

In the coating samples, the microstructure of the surface of the castings showed almost no evident chill layer. The control samples had a chill layer and a columnar crystal layer extending from the surface toward the interior.

Use of the electron probe microanalyzer (EPMA) to determine distribution of various elements in the superficial layer of casting plates showed the reactive layer contained $\mathrm{Si}$ and $\mathrm{P}$ in control samples. In coating samples, it showed a small reactive layer contained impure elements though there was a high density of $\mathrm{Zr}$ of the surface layer of the castings.

The results are suggested that it is possible to improve a reactive layer of the surface of pure titanium denture base cast using phosphate-bonded investment by coating of the surface of the refractory models.
\end{abstract}

Key words : titanium, castings, phosphate-bonded investment, coating material

\section{I. 緒 言}

純チタンは耐蝕性, 生体適合性および比強度に優れてい るために，歯科領域への応用はますます盛んになってきて いる11.しかしながら，改善されるべき点も多々あり，さ

\section{大阪歯科大学大学院歯学研究科歯科補綴学専攻}

*大阪歯科大学歯科補経学第一講座

Graduate School of Dentistry (Prosthodontics), Osaka Dental University

*First Department of Prosthodontics, Osaka Dental University 平成 11 年 5 月 17 日受付
まざまな研究が行われている2

著者らは純チタン鋳造の改善されるべき問題点の 1 つと して，反応層に着目し検討を重ねてきた ${ }^{7 \sim 9)}$. 鋳造体表層 に生じる反応層の存在は純チタンの機械的性質, 硬度に影 響を及ほすを同時に反応層に含まれる不純物の存在はその 生体適合性にも影響を及ほすものではないかと考え $3^{10 \sim 12)}$.

従来から，鋳造床製作法はロストワックス法が多用され ているが，純チタンは高温での活性が高いために，良好な 鋳造体を得るためには使用する埋没材の選択が重要とな る. 著者らは安定した膨張が得られ, 操作性, 保存性およ 
表 1 Physical properties of investment materials 埋没材の物理的性質

\begin{tabular}{lcccccc}
\hline \hline & $\begin{array}{c}\text { 混液比 } \\
(\mathrm{L} / \mathrm{P})\end{array}$ & $\begin{array}{c}\text { 硬化時間 } \\
(\mathrm{min})\end{array}$ & $\begin{array}{c}\text { 硬化膨張率 } \\
(\%)\end{array}$ & $\begin{array}{c}\text { 熱膨張率 } \\
(\%)\end{array}$ & $\begin{array}{c}\text { 圧縮強さ } \\
\text { 乾燥時 }\end{array}$ & $\begin{array}{c}(\mathrm{MPa}) \\
\text { 焼却時 }\end{array}$ \\
\hline TAIVEST & 0.13 & 5.00 & 0.02 & 1.13 & 24.5 & 27.5 \\
T-INVEST C \& B & 0.13 & 10.4 & 0.66 & 1.33 & 15.8 & 7.0 \\
\hline
\end{tabular}

び経済性の点からリン酸塩系埋没材を使用してきたが，同 時に鋳造時に生じる埋没材との反応層の改善にもさまざま な検討を加えてきた

そこで今回, 著者らは生体粘膜に直接接触する純チタン 鋳造床粘膜面表層に生じる反応層を改善するため, 耐火模 型に純チタンと反応しにくいジルコニア 13,14)をコーティン グすることを試みたので報告する.

\section{II. 材料と方法}

\section{1. 材料}

実験には CPチタン JIS 規格 2 種（日本ステンレス社 製)を用いた。

複印象材は複印象用シリコーン印象材（デュプリコー ン，松風社製）を用いた。

埋没材は市販リン酸塩系埋没材のなかから, TAIVEST （大成歯科工業社製）および T-INVEST C \& B (大成歯 科工業社製）を用いた。使用した埋没材の物理的性質を表 1 に示す。

コーティング材はジルコニアゾル（AZS-NB，日本触 媒化学社製) にジルコニア粉末 (OZC-OS 6, 大阪セメン ト社製）を添加したものを用いた。

\section{2. 鋳造床の製作}

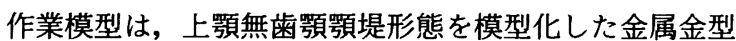
をシリコーン印象材（信越シリコーン KE-113，信越化 学工業(株)) で印象し, 超硬質石育 (ニューフジロック, ジーシー社製）を注入して製作した。

耐火模型は, 作業模型を複印象用シリコーン印象材で複 印象し, 上記の埋没材を表 1 に示す混液比で練和し, 注入 して製作した。なお，耐火模型は各条件について 5 個ずつ 製作した。

耐火模型表面のコーティングは，刷毛を用いてコーティ ング材を 2 度塗りした。なお，実験はコーティング材を塗 布したコーティング試料と，比較対照としてコーティング 材を塗布しないコントロール試料の 2 条件で，その使用組 合せは表 2 に示し, 以後略号を用いる。

蠟型は厚さ $0.55 \mathrm{~mm}$ のシートワックス（松風社製）を 耐火模型に圧接し, 口蓋後縁中央に直径 $6 \mathrm{~mm}$ のスプルー を植立して製作した。

埋没はリングレス法で行い，鋳型の焼却には，自動昇温
表 2 Experimental conditions 実験条件

\begin{tabular}{ccc}
\hline \hline 埋没材 & 条件 & 略号 \\
\hline TAIVEST & ジルコニアコーティンク & T-ZR \\
& コントロール & T-CONT \\
T-INVEST C \& B & $\begin{array}{c}\text { ジルコニアコーティンク } \\
\text { コントロール }\end{array}$ & CB-ZR \\
& CB-CONT \\
\hline
\end{tabular}

係留装置付電気炉 (AUTO FURNASE QM-I, ジーシー 社製）を使用した。 TAIVEST では室温から $850^{\circ} \mathrm{C}$ まで 5 時間で昇温, $850^{\circ} \mathrm{C} て ゙ 2$ 時間係留したのち, 灲内放冷し た。また，T-INVEST C \& B では室温から $250^{\circ} \mathrm{C}$ まで 2 時間で昇温, $250^{\circ} \mathrm{C} て ゙ 1$ 時間係留後, $800^{\circ} \mathrm{C}$ まで 2 時間で 昇温， $800^{\circ} \mathrm{C} て ゙ 1$ 時間係留したのち，炉内放冷した。

鋳造は真空加圧鋳造機（オートキャスト HC-III，ジー シー社製）を使用し，加圧条件 7 気圧で室温にて行った。

\section{3. 実験方法}

1）耐火模型粘膜面の表面あらさ

表面あらさ形状測定器（サーフコム $570 \mathrm{~A}$, 東京精密社 製）を用い, 焼却前後の耐火模型粘膜面中央部において, 測定長さ $2.5 \mathrm{~mm}$, 測定速度 $0.3 \mathrm{~mm} / \mathrm{s}$, カットオフ波長 $0.8 \mathrm{~mm}$ の条件にて, 10 点平均あらさ $(\mathrm{Rz})$ を測定した。 また, コーティング試料とコントロール試料との有意差検 定をスチューデント式 $\mathrm{t}$ 検定を用い行った。

2）耐火模型との型ばなれの肉眼観察

鋳造後，鋳型加鋳造床を取り出し，鋳造床と耐火模型 との型ばなれの肉眼観察を行った。

3）鋳造床粘膜面の表面あらさ

鋳造床鋳放し面の表面あらさの測定を，粘膜面中央部に ついて耐火模型の表面あらさと同一条件で行った。

\section{4）鋳造床粘膜面表面の走查電子顕微鏡観察}

鋳放し面上の埋没材をエバンス嵗刻刀にて除去した鋳造 床粘膜面表面を走查電子顕微鏡（JXA-8600 SUPERPROBE，日本電子社製）を用いて，コーティング試料で は倍率 50 倍と 250 倍で，コントロール試料では 250 倍で 観察を行った。

5）鋳造床粘膜面表層の硬さ

鋳造床を精密低速切断機（ISOMET LOW SPEED SAW，BUEHLER 社製）を用い，可及的中央で切断した 後, エポキシ樹脂包埋し, 而水ペーパーおよび $0.3 \mu \mathrm{m}$ 径 


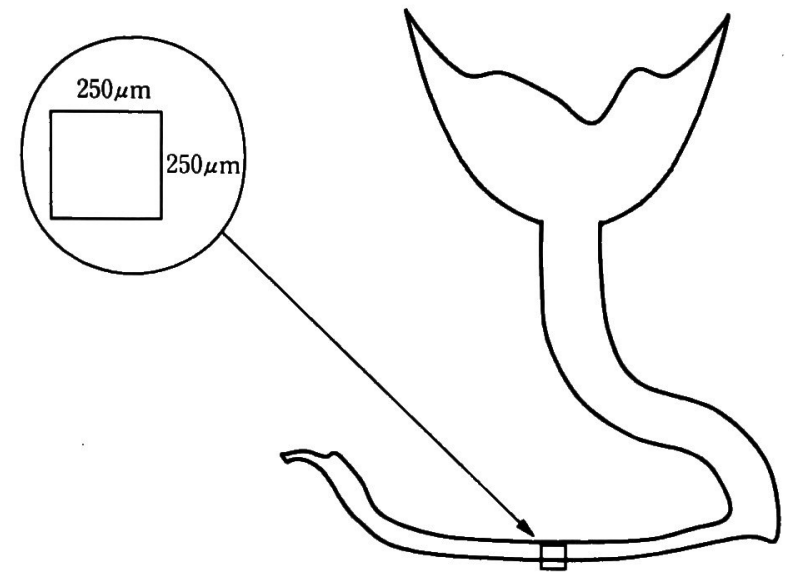

图 1 Area analyzed in casting 金属床表層の分析部位

のダイヤモンドペーストにて鏡面研磨したものを観察試料 とした. 鋳造床粘膜面表面下の $30 \mu \mathrm{m}$ から $240 \mu \mathrm{m}$ まで を $15 \mu \mathrm{m}$ 間隔で, 微小硬度計（MMT-3 型, マッザワ社 製）を用い, 荷重 $0.245 \mathrm{~N}$ (25gf), 荷重時間 20 秒, 顕 微鏡倍率 1000 倍の測定条件でビッカース硬さ試験を行っ た.また,コーティング試料とコントロール試料との有意 差検定をスチューデント式 $\mathrm{t}$ 検定を用いて行った.

6）鋳造床粘膜面表層の金属組織観察

樹脂包埋試料を $47 \%$ フッ化水素酸：61\% 硝酸：蒸留水 を $8: 3: 31$ の配合比で混合した溶夜で約 2 秒間腐蝕した ものを観察試料とし, 光学顕微鏡 (BX 60, オリンパス社 製）を用い，顕微鏡倍率 500 倍で行った。

7）鋳造床粘膜面表層の EPMA 分析

$\mathrm{Ti}$ と埋没材の構成元素である $\mathrm{O}, \mathrm{Si}, \mathrm{P}, \mathrm{Mg}, \mathrm{Al}, \mathrm{Zr}$ の 7 元素について, EPMA (JXA-8600 SUPERPROBE, 日本電子社製) を用い, 濃度分布と定量分析を 行った. 図 1 の模式図に示す鋳造床粘膜面表層 $250 \mu \mathrm{m} \times$ $250 \mu \mathrm{m}$ の範囲を $1 \mu \mathrm{m}$ 間隔で計測して元素濃度分布を マッピング表示した。 また, 定量分析は鋳造床粘膜面表層 から内部に向い $5 \mu \mathrm{m} \times 10 \mu \mathrm{m}$ 間隔で連続的に 20 力所を 分析した。なお，定量分析はZAF 補正法を用いた。

\section{III. 結 果}

\section{1. 耐火模型粘膜面の表面あらさ}

耐火模型粘膜面焼却前後の表面あらさ $(\mathrm{Rz})$ の測定結 果を表 3 に示す. 焼却前の耐火模型粘膜面の表面あらさ は, T-ZR で $5 \mu \mathrm{m}, \mathrm{T}-\mathrm{CONT}$ で $7 \mu \mathrm{m}, \mathrm{CB}-\mathrm{ZR} て ゙ 11$ $\mu \mathrm{m}, \mathrm{CB}-\mathrm{CONT}$ で $19 \mu \mathrm{m}$ とコーティング試料のほうが TAIVEST では 5\%の危険率で T-INVEST C \& B では $1 \%$ の危険率で有意に小さい值を示した．焼却後の耐火模 型粘膜面の表面あらさは, T-ZR で $30 \mu \mathrm{m}, \mathrm{T}-\mathrm{CONT}$ で
表 3 Surface roughness of refractory models (Rz) 耐火模型の表面あらさ (Rz)

\begin{tabular}{lrr}
\hline \hline \multicolumn{1}{c}{ 条件 } & \multicolumn{1}{c}{ 焼却前 } & \multicolumn{1}{c}{ 焼却後 } \\
\hline $\mathrm{T}-\mathrm{ZR}$ & $5 \mu \mathrm{m}(1.1)$ & $30 \mu \mathrm{m}(3.8)$ \\
$\mathrm{T}-\mathrm{CONT}$ & $7 \mu \mathrm{m}(0.7)$ & $7 \mu \mathrm{m}(0.3)$ \\
$\mathrm{CB}-\mathrm{ZR}$ & $11 \mu \mathrm{m}(0.8)$ & $12 \mu \mathrm{m}(1.5)$ \\
$\mathrm{CB}-\mathrm{CONT}$ & $19 \mu \mathrm{m}(2.4)$ & $15 \mu \mathrm{m}(2.0)$ \\
\hline
\end{tabular}

( ) : S.D.

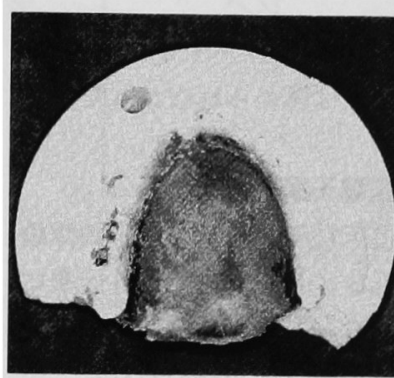

$\mathrm{T}-\mathrm{ZR}$

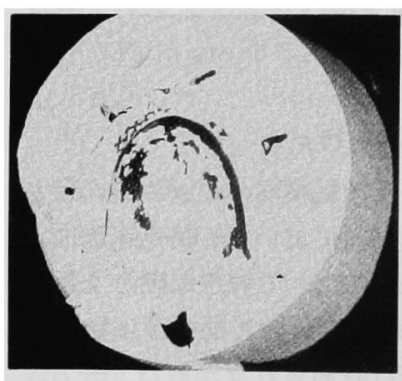

CB-ZR

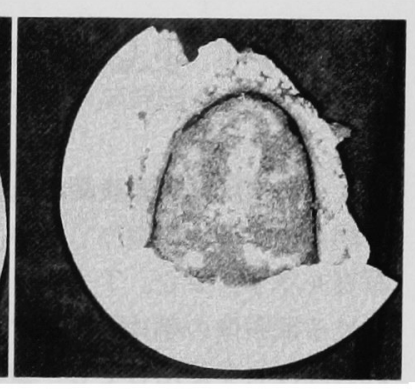

T-CONT

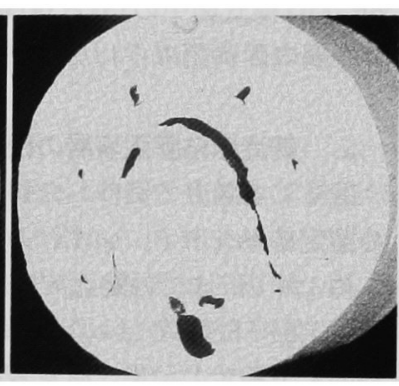

CB-CONT
目 2 Macroscopic observation of residual investment materials on the surface of casting plates 鋳造床と鋳型との型ばなれの肉眼観察

$7 \mu \mathrm{m}$ と TAIVEST ではコーティング試料のほうが焼却前 とは逆に $1 \%$ の危険率で有意に大きい值を示した。一方, T-INVEST C \& B では CB-ZR で $12 \mu \mathrm{m}, \mathrm{CB}-\mathrm{CONT} て ゙$ $15 \mu \mathrm{m}$ とコーティング試料とコントロール試料とに有意 な差は認められなかった。

\section{2. 埋没材との型ばなれの肉眼観察}

掘り出し直後の鋳造床と鋳型との状態を図 2 に示す. い ずれの埋没材を用いてもコーティング試料を用いた場合の ほうが埋没材の付着が少なく型ばなれが良好であった。

\section{3. 鋳造床粘膜面の表面あらさ}

鋳造床粘膜面の表面あらさの測定結果を表 4 に示す. 鋳 造床の表面あらさは, 鋳型焼却後の結果と同様の傾向がみ られた.すなわち, TAIVESTでは T-ZR で $25 \mu \mathrm{m}, \mathrm{T}$ CONT で $13 \mu \mathrm{m}$ とコーティング試料のほうが $1 \%$ の危険 率で有意に大きい值を示し, T-INVEST C \& B では CB- 
表 4 Surface roughness of castings ( $\mathrm{Rz})$ 鋳造床表面の表面あらさ $(\mathrm{Rz})$

\begin{tabular}{lc}
\hline \multicolumn{1}{c}{ 条件 } & 表面あらさ \\
\hline $\mathrm{T}-\mathrm{ZR}$ & $25 \mu \mathrm{m}(2.2)$ \\
$\mathrm{T}-\mathrm{CONT}$ & $13 \mu \mathrm{m}(2.0)$ \\
$\mathrm{CB}-\mathrm{R}$ & $14 \mu \mathrm{m}(1.5)$ \\
$\mathrm{CB}-\mathrm{CONT}$ & $13 \mu \mathrm{m}(1.6)$ \\
\hline & $(\quad): \mathrm{S} . \mathrm{D}$.
\end{tabular}

ZR で $14 \mu \mathrm{m}, \mathrm{CB}-\mathrm{CONT} て ゙ 13 \mu \mathrm{m}$ とコーティング試料 とコントロール試料間に有意な差は認められなかった。

\section{4. 鋳造床粘膜面表面の走查電子顕微鏡観察}

図 3 に各条件で製作した鋳造床粘膜面の走查電子顕微鏡 写真を示す。また，T-ZR と CB-ZR については各倍率に おける観察像の模式図を示す。コントロール試料ではいず れの埋没材を使用しても一様な金属表面が認められた。一 方，T-ZR では模式図中の (1) と (2) に相当する部分, CB$Z R$ では模式図中の (3) と (4) に相当する部分において異な る金属表面が認められた。

\section{5. 鋳造床粘膜面表層の硬さ}

図 4 に各条件で製作した鋳造床粘膜面のビッカース硬さ の測定結果を示す．いずれの試料においても鋳造床表面か ら約 $120 \mu \mathrm{m}$ までは鋳造床内部に比べて大きな硬さを示し た. TAIVEST ではコントロール試料とコーティング試 料間に $\mathrm{t}$ 検定の結果，有意差は認められなかった。一方， T-INVEST C \& B では表層 $30 \mu \mathrm{m}$ でコントロール試料 のほうが，コーティング試料よりも $1 \%$ の危険率で有意に 大きい値を示したが， $45 \mu \mathrm{m}$ から $240 \mu \mathrm{m}$ の深さでは両試 料間に有意差は認められなかった。

\section{6. 鋳造床粘膜面表層の金属組織観察}

図 5 に各条件で製作した鋳造床粘膜面の金属組織を示 す、いずれの埋没材を用いてもコーティング試料では，明 確なチル層はほとんど認められず，柱状晶帯が粘膜面表面 から約 $120 \mu \mathrm{m}$ 付近まで観察された。一方，コントロール 試料では粘膜面表面から約 $30 \mu \mathrm{m}$ 付近までチル層, 約 $120 \mu \mathrm{m}$ 付近まで柱状晶带の順に存在した。 また，腐食処 理によって, チル層, 柱状晶帯には強く腐食された部分が 観察された。

\section{7. 鋳造床粘膜面表層の EPMA 分析}

図 6，7 に各条件で製作した鋳造床粘膜面の $\mathrm{Ti}$ と埋没 材の構成元素である $\mathrm{O}, \mathrm{Si}, \mathrm{P}, \mathrm{Mg}, \mathrm{Al}, \mathrm{Zr}$ の濃度分布 と定量分析結果を示す。

各元素の濃度分布は 12 段階の色調で表している．また， 定量分析結果のグラフは綐軸に wt \% を，横軸には鋳造床
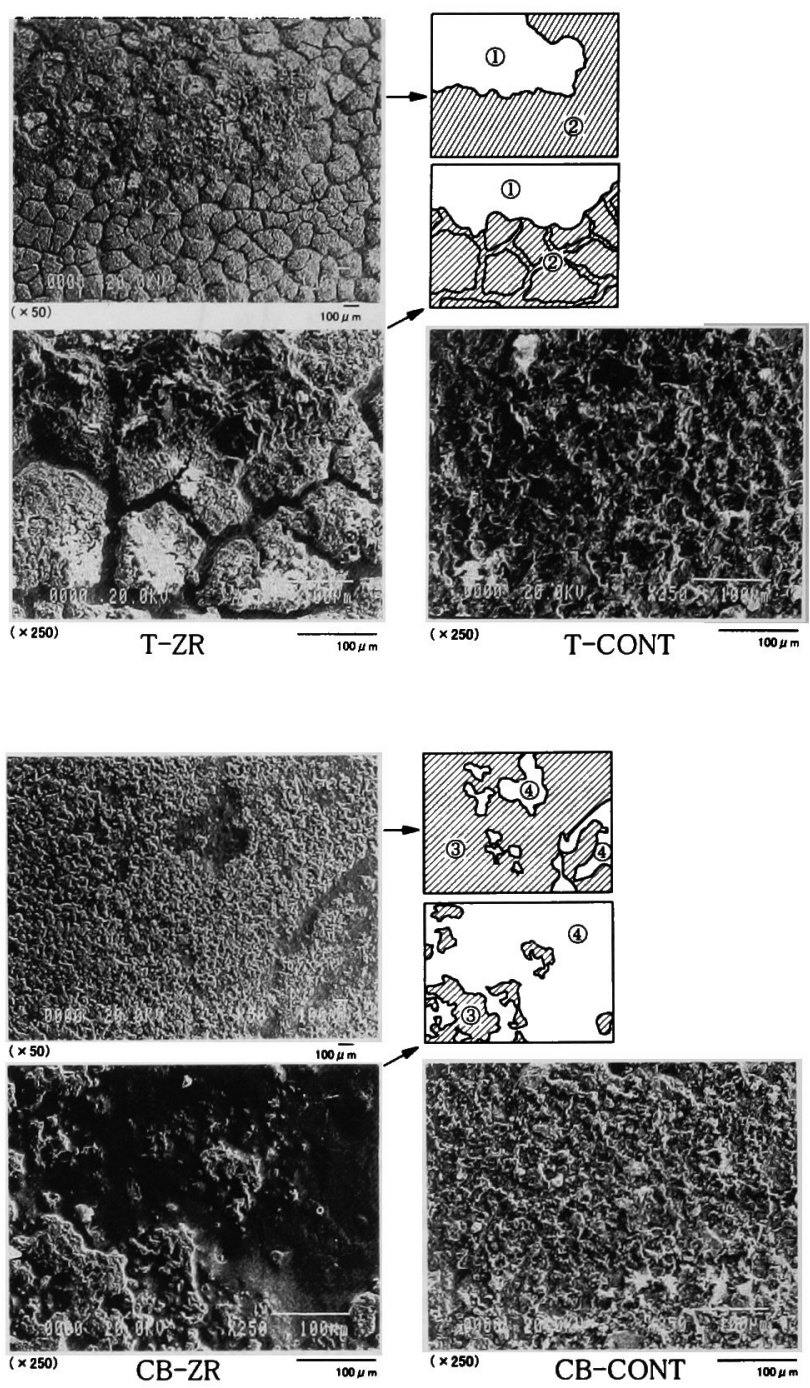

図 3 SEM photographs of casting surface and schematic illustration 鋳造床表面の SEM 像および模式図

粘膜面表面からの深さを示している．また，Ti の濃度分 布で示す図中aは，定量分析結果の図中横軸の 0 点と一致 し，図中 a から右側が鋳造床内部を示している.

いずれの埋没材を用いても，Ti 表面から図中左側に $\mathrm{O}, \mathrm{Si}, \mathrm{P}, \mathrm{Mg}, \mathrm{Al}, \mathrm{Zr}$ の存在が認められたが，その濃 度分布はコーティング試料のほうがコントロール試料より も存在する範囲が狭く濃度も低い値を示した。

1） TAIVEST を用いた鋳造床表層の EPMA 分析結果

（1）コーティング試料の場合

$\mathrm{Ti}$ は, 表面から約 $20 \mu \mathrm{m}$ まで, 内部と比較して濃度の 低い部位が存在した。 $\mathrm{O}$ は, 表面から $15 \mu \mathrm{m}$ まで, 内部 と比較して濃度の高い部分が存在していた. Si，Pは, 表 面から約 $20 \mu \mathrm{m}$ まで, 濃度の高い層が部分的に対応して 存在していた。 $\mathrm{Mg}, \mathrm{Al}$ は鋳造床表層にはほとんど認めら 



図 4 Surface hardness of castings 鋳造床表層の硬さ
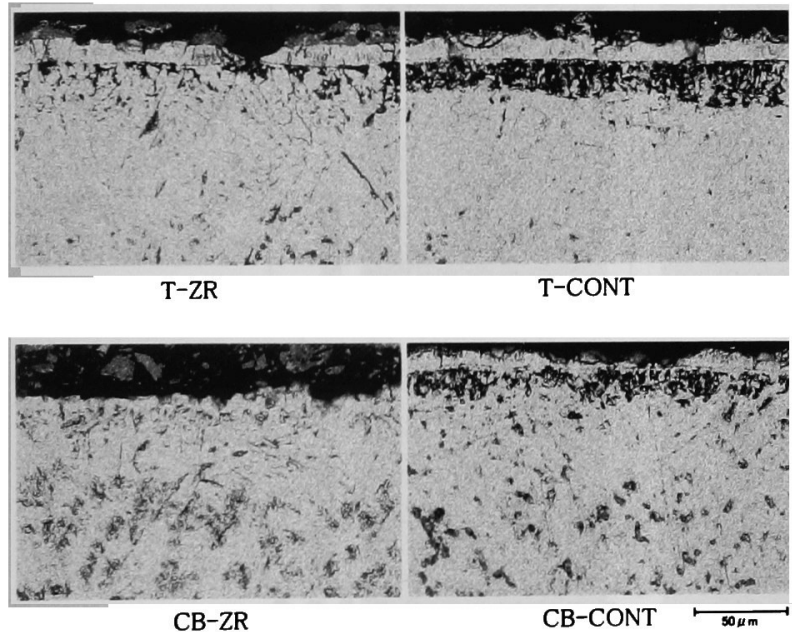

图 5 Microstructure of cross section around casting surface 鋳造床表層の金属組織

れなかった. $\mathrm{Zr}$ は, 表面から約 $20 \mu \mathrm{m}$ まで, 濃度の高い 層が帯状に連続して存在していた。

(2) コントロール試料の場合

Ti は, 表面から約 $30 \mu \mathrm{m}$ まで, 内部と比較して濃度の 低い部位が存在した． $\mathrm{O}$ は, 表面から約 $15 \mu \mathrm{m}$ まで内部 と比較して濃度の高い部位が存在した. $\mathrm{Si}, \mathrm{P}$ は, 表面か ら約 $30 \mu \mathrm{m}$ まで, 濃度の高い層が帯状に連続して存在し ていた. $\mathrm{Mg}, \mathrm{Al}, \mathrm{Zr}$ は, いずれの元素も鋳造床表層には ほとんど存在が認められなかった。

2） T-INVEST C \& B を用いた鋳造床表層の EPMA 分析結果

（1）コーティング試料の場合

Ti は, 表面から約 $10 \mu \mathrm{m}$ まで, 内部と比較して濃度の 低い部位が存在した。 $\mathrm{O}$ は, 表面から $10 \mu \mathrm{m}$ まで, 内部
と比較して濃度の高い部位が存在した. $\mathrm{Si}, \mathrm{P}, \mathrm{Mg}, \mathrm{Al}$ は鋳造床表層にはほとんど認められなかった，Zr は，表 面から約 $15 \mu \mathrm{m}$ まで, 内部と比較してゃや濃度の高い部 位が存在した。

（2）コントロール試料の場合

$\mathrm{Ti}$ は, 表面から約 $25 \mu \mathrm{m}$ まで, 内部と比較して濃度の 低い部位が存在した。 $\mathrm{O}$ は, 表面から約 $15 \mu \mathrm{m}$ まで濃度 の高い部位が存在した. Si，Pは，表面から約 $30 \mu \mathrm{m}$ ま で濃度の高い層と低い層が混在しながら帯状に存在してい た. $\mathrm{Mg}$ はほとんど存在が認められながった. $\mathrm{Al}, \mathrm{Zr}$ は, 表面から約 $10 \mu \mathrm{m}$ まで, 内部と比較してゃや濃度の高い 部位が存在した.

\section{IV. 考 察}

純チタン鋳造体表層には埋没材との反応によって，チタ ン特有の反応層が生じる7,15 17). 反応層はサンドブラスト や化学研磨などによって除去することは可能であるとした 報告もあるが ${ }^{18)}$ ，必ずしも補綴装置の寸法精度にとって好 ましいものではない.したがって，反応層の改善を目的と した純チタン鋳造用埋没材の研究開発が進められている が19,20), 著者らは前述したりン酸塩系埋没材の利点からそ の応用について検討を加えている.

今回, 著者らは 1 つの試みとして, リン酸塩系埋没材を 用いて製作した耐火模型表面を純チタンとの反応性が低い 物質でコーティングし興味ある知見を得たので，以下，そ の結果について考察する.

実験に使用した埋没材は, コーティング法が反応層抑制 に効果が認められるかどうかを検討する目的で, 反応層が 生じやすいと考えられる石英を主成分とした市販リン酸塩 系埋没材 TAIVEST と, チタン鋳造用リン酸塩系埋没材 

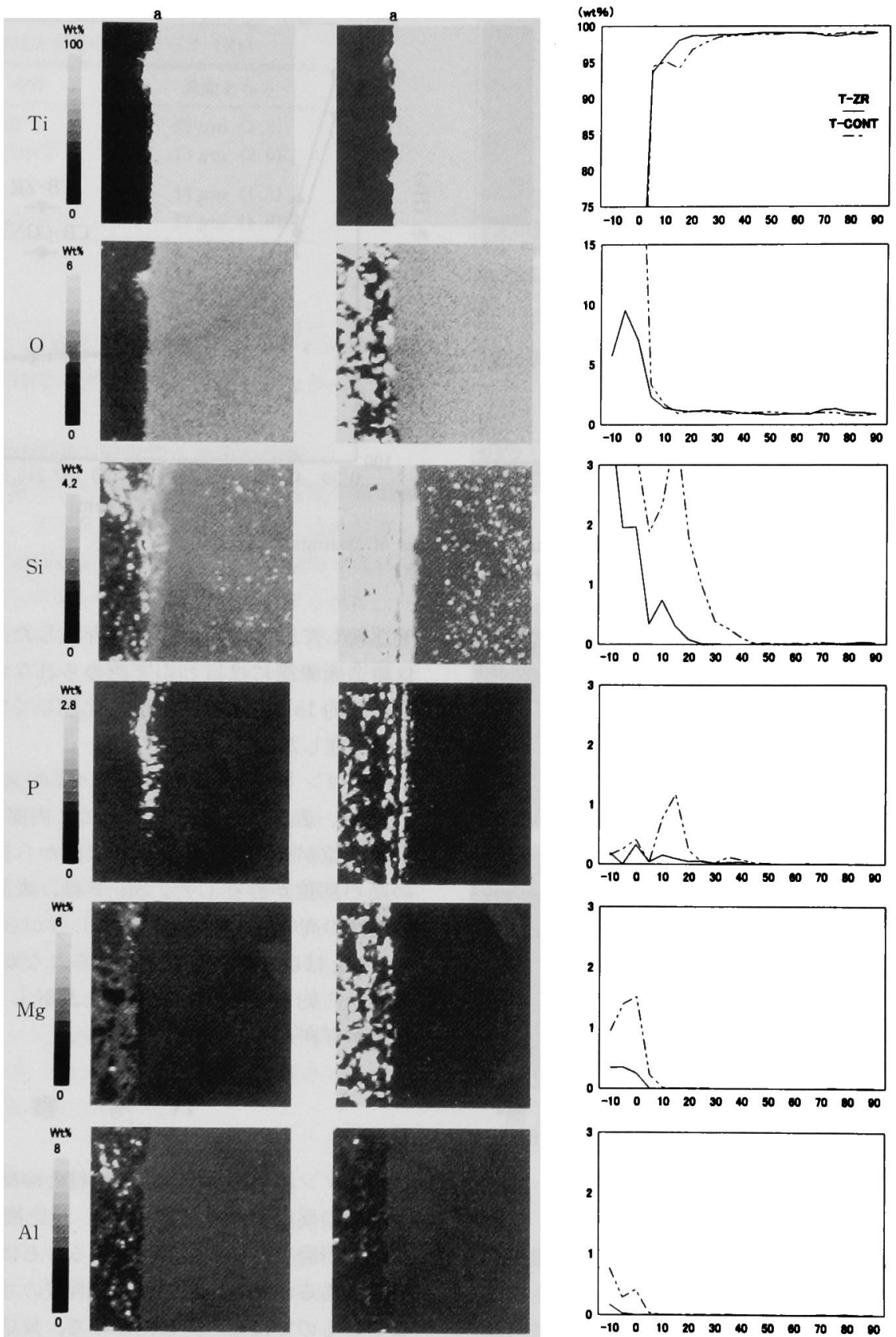

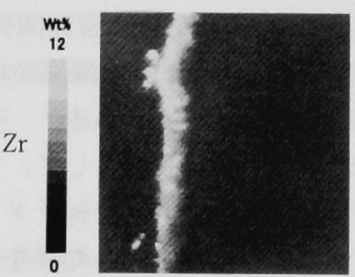

$T-Z R$

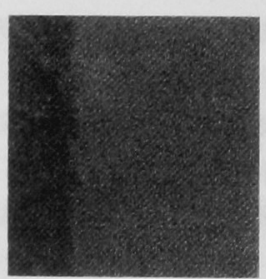

T-CONT

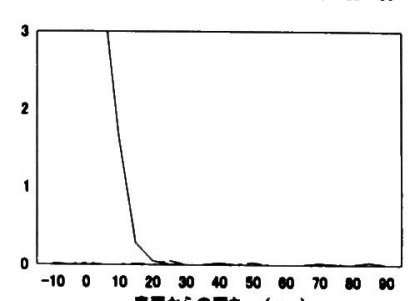

图 6 Density and quantitative analysis of various elements in the casting (TAIVEST) 鋳造床表層の各種元素濃度・定量分析結果 (TAIVEST) 

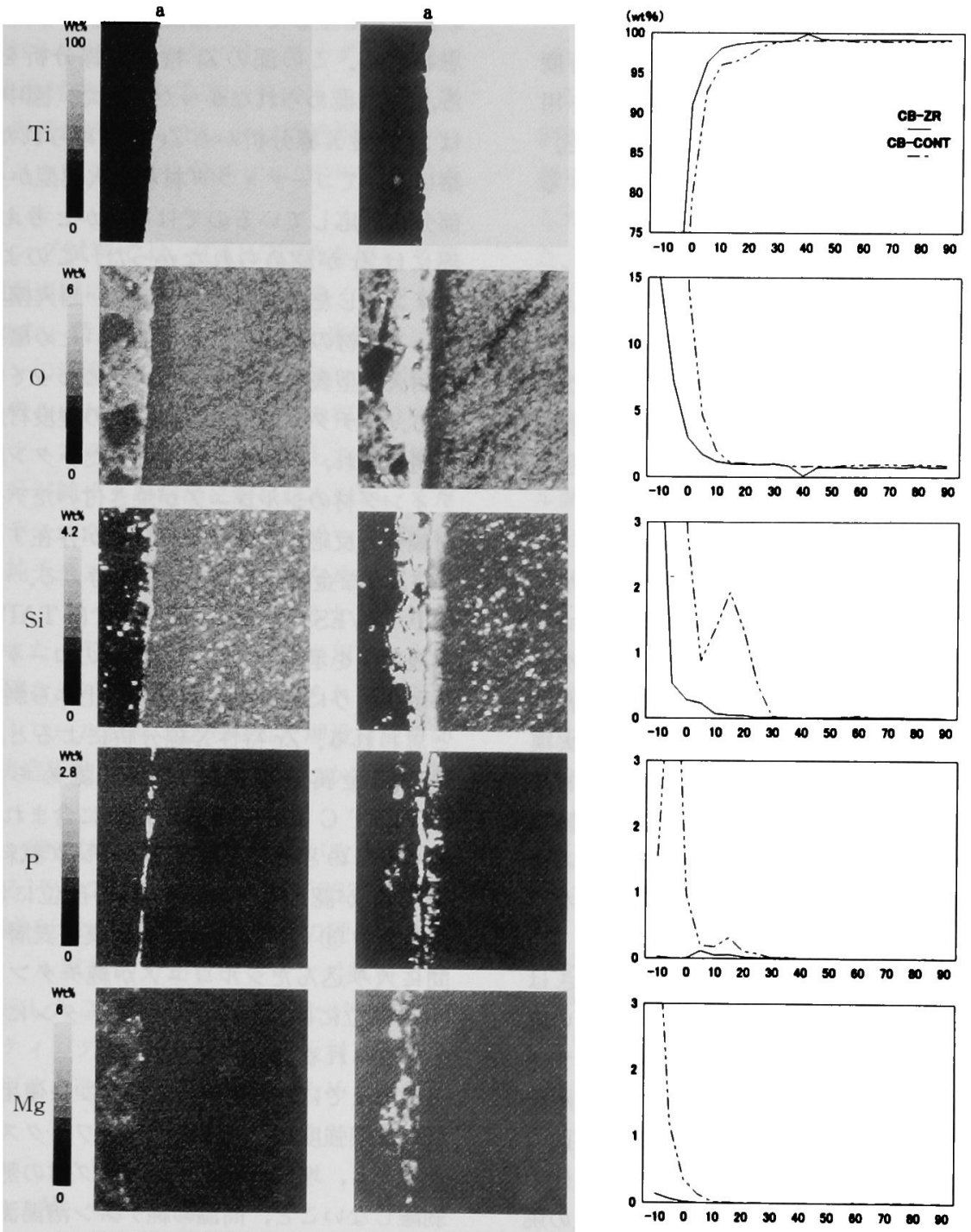

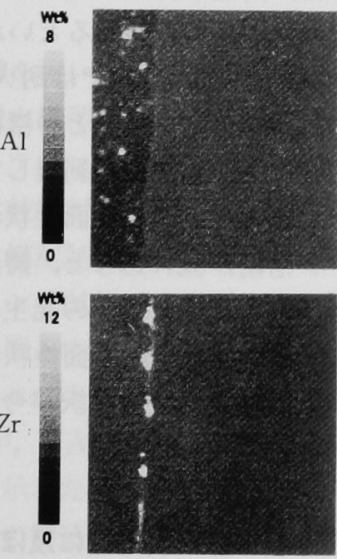

CB-ZR
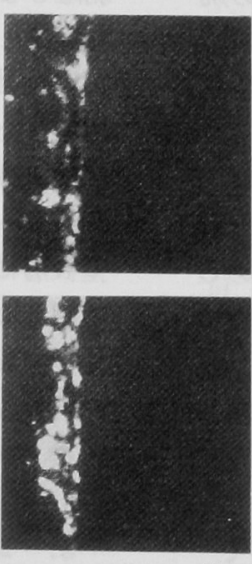
CB-CONT
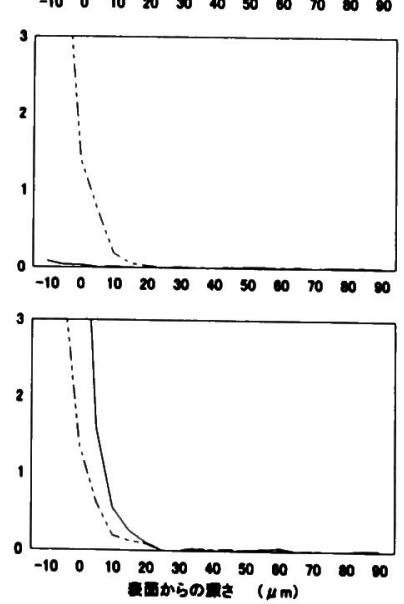

国 7 Density and quantitative analysis of various elements in the casting (T-INVEST C \& B) 鋳造床表層の各種元素濃度・定量分析結果 (T-INVEST C \& B) 
T-INVEST C \& B の 2 種類を用いた.

コーティング材としてジルコニアゾルに耐熱温度 $2,720^{\circ} \mathrm{C}$ を有するジルコニア粉末を添加した塗型材を用 い, 耐火模型表面に塗布しジルコニア皮膜を形成させた。 ジルコニア皮膜厚さは非接触型レーザ測定器にて測定する と約 $23 \mu \mathrm{m}$ であった。

1. コーティング法による耐火模型の表面性状について コーティングしない耐火模型粘膜面の表面あらさは $\mathrm{T}$ INVEST C \& B がTAIVEST よりも大きい值を示した. これは T-INVEST C \& B の耐火材粒子の結合力が弱い ため, 複印象材からの撤去時に耐火模型の表面性状が悪く なったことがうかがえる.

コーティングした耐火模型の表面あらさは, TINVEST C \& B がTAIVEST よりも大きい值を示した. 肉眼観察でもコーティングした耐火模型表面の状態はコー ティング材が乾燥し，T-INVEST C \& B では光沢のない ざらついた表面性状，TAIVEST では光沢のある滑沢な 表面性状を示した。これは T-INVEST C \& B の耐火模 型表層の耐火材粒子が粗いため, 耐火材結晶粒子間にジル コニアの微細粒子が入り込み, TAIVEST では耐火模型 の表面性状が良好で, ジルコニアの微細粒子が入り込みに くいため, T-INVEST C \& B よりも表面性状がよくなっ たと考えられる。

しかし, 焼却後の耐火模型粘膜面の表面あらさは TAIVEST のほうがT-INVEST C \& B よりも大きい值 を示した，肉眼観察によると，TAIVEST ではコーティ ング材が耐火模型から鱗状に剥離し，ところどころに耐火 模型本来の表面色が認められた。 また, 耐火模型粘膜面の 口蓋中央の平坦な部分よりも，歯槽頂に近い斜面部分の コーティング材の剝離が多く認められた。これは蠟型の焼 却時にワックスに引かれて剥離したものではないかと思わ れる.コーティング材の鱗状の剥離片は, 埋没材の熱膨張 がコーティング材の熱膨張よりも大きかったために生じた ものと考えられる.一方，T-INVEST C \& Bではコー ティング材が耐火模型から粉末状に剝離していたが，一層 のコーティング材は残り，耐火模型本来の表面色は認めら れなかった。これは,コーティング時に耐火模型表面に 残った粗いジルコニア粒子がワックスに引かれて剝離し, 埋没材粒子間に入り込んだジルコニアの微細粒子は剝離し なかったためではないかと考えられる。

\section{2. コーティング法による鋳造床の表面性状について}

走査電子顕微鏡による鋳造床表面の観察では図 3 のよう な像を示した。

TAIVESTにおいて模式図で示す (1)の部位は，コー ティング処理を施していないコントロール試料と同様の金 属表面像を示している。この部位は，前述の耐火模型本来
の表面色を呈していた部位と対応しているのではないかと 思われる.この部の $\mathrm{Zr}$ 特性 X 線分析を行ってみたとこ ろ, Zr は認められなかった. また，図中 (2)で示す部分に は $\mathrm{Zr}$ 特性 $\mathrm{X}$ 線分析から $\mathrm{Zr}$ が認められた。これは肉眼観 察においてコーティング材が耐火模型から剝離しなかった 部分に対応しているのではないかと考える. 図中 (2)の溝 部には $\mathrm{Zr}$ が認められなかった。このような現象はコー ティングした耐火模型焼却時に，耐火模型の熱膨張がコー ティング材の熱膨張よりも大きいため亀裂が生じ，亀裂部 は耐火模型表面が露出した状態になっているためと考えら れる. 純チタンの溶湯は亀裂部の埋没材成分と反応しなが ら鋳込まれ，凝固する．凝固したチタン床表面には，コー ティング材のジルコニアが焼き付いたチタン部分と，埋没 材成分と反応したチタン部分とが存在することになり，図 3 のような金属表面像を呈すと考える。

T-INVEST C \& B においては TAIVEST と異なる金 属表面像を示した．耐火模型上のコーティング材は，図 3 に示すように焼却後も耐火模型上から豩離しなかったもの と思われる。 $\mathrm{Zr}$ 特性 X 線分析によると，コントロール試 料では金属表層全体に $\mathrm{Zr}$ が認められた。これは $\mathrm{T}$ INVEST C \& B の埋没材成分に含まれるジルコニアに由 来するものと考える.コーティング試料では図中 (3)の部 位に $\mathrm{Zr}$ が認められ，図中 (4)の部位には認められなかっ た. 図中 (3)の部位には, 而火模型表層の埋没材結晶粒子 間に入り込んだジルコニアが純チタンに焼き付き，図中 (4)の部位にはジルコニアが純チタンに焼き付かなかった と考えられる。

これまでに，ワックスパターンに使用するコーティング 材の皮膜強度は, 鋳型の焼却時ワックスに引かれて剥離し ないこと，埋没材とコーティング材の熱膨張の差によって 剥離しないこと，高温の純チタン溶湯流入によって剥離し ないことなどの条件が必要であるといわれてきた ${ }^{21)}$. 今回 の実験において, TAIVEST では耐火模型の表面性状が 滑沢な大めに，コーティング材との機械的な結合が得られ ず，焼却時にコーティング材が剝離してしまう結果となっ た.コーティング材が剥離し表面性状が粗となった耐火模 型表層にチタン溶湯が流れ込むと，鋳造体表層の表面性状 も粗となり，溶湯の乱流，鋳巣の発生の可能性も考えられ る ${ }^{22)}$. したがって, 埋没材の表面性状や熱膨張などの条件 に合った，コーティング法の選択が今後の重要な課題とな ることが示唆された.

\section{3. コーティング法が反応層に及ぼす影響について}

鋳造床粘膜面表層の金属組織観察において，いずれの埋 没材を使用してもコントロール試料では，これまでにも報 告されているリン酸塩系埋没材を用いた場合に生じる反応 層が存在していた。すなわち，鋳造体表層から金属凝固組 織であるチル層, 柱状晶帯が存在し，チル層部には，Oが 
多く含まれる $\alpha$-case と腐蝕処理によって強く腐蝕された $\mathrm{Si}, \mathrm{P}$ が多く含まれる層が存在した。これはチタン溶湯に 溶け込んだ $\mathrm{O}$ と埋没材成分である $\mathrm{Si}, \mathrm{P}$ のうち, Oは固 溶限が大きいため表層に残留し, $\mathrm{Si}, \mathrm{P}$ は固溶限が小さい ために結晶粒界にストリング状に偏析する7,15 17)ことが原 因であると考える。

一方，コーティング試料では，TAIVESTを用いて製 作した鋳造床粘膜面表層に O, Si, P, Zr が多く存在する 反応層が認められた. 特に $\mathrm{Zr}$ および $\mathrm{O}$ の元素濃度は高 く,これは純チタンの溶湯にジルコニアコーティング材が 焼き付いたためと考えられる.また， Si，Pの存在は先の 考察 1 から，コーティング材の亀裂部に露出した耐火模型 表層から埋没材成分が純チタン溶湯に溶け込んだか, また は, 焼却時にコーティング材の微細な亀裂に沿って埋没材 の成分が浸入し, 純チタン溶湯に溶け込んだためと考えら れる.しかし，コントロール試料と比較すると Si, Pの 濃度は低かった。また，T-INVEST C \& B を用いたコー ティング試料は明確なチル層はほとんど認められず, 元素 分析結果でもコントロール試料で認められた埋没材成分の $\mathrm{O}, \mathrm{Si}, \mathrm{P}, \mathrm{Zr}$ は鋳造床粘膜面のごく表層にしか存在しな かった.

一般に, 純チタン鋳造体表層に不純物元素が取り込まれ ると硬度が上昇する7,8).このことは，T-INVEST C \& B を用いて製作した純チタン鋳造床粘膜面表層の硬さは表層 $30 \mu \mathrm{m}$ でコントロール試料の方がコーティング試料より も若干大きい值を示したことと一致する。したがって, 耐 火模型表層のコーティング材がリン酸塩系埋没材と純チ夕 ンとの間に生じる反応の改善に効果があったためと考えら れる.

\section{V. 結 論}

リン酸塩系埋没材を用いた純チタン鋳造床の反応層の改 善を目的として, 耐火模型をジルコニアでコーティングす ることを試み, コーティング試料と従来の埋没方法でのコ ントロール試料を比較検討し，以下の結論を得た。

1. 焼却前の耐火模型粘膜面の表面あらさは, いずれの 埋没材でもコーティング試料のほうが小さい值を示した. 焼却後の粘膜面の表面あらさは, T-INVEST C \& B では コーティング試料とコントロール試料との間に顕著な差は 認められなかったが, TAIVEST ではコーティング試料 のほうが大きい值を示した。

2. 掘り出し直後の鋳造床は, コーティング処理した耐 火模型を用いた場合，埋没材の付着が少なく型ばなれが良 好であった。

3. 鋳造床鋳放し面での粘膜面の表面あらさは, 焼却後 の表面あらさの結果と同じ傾向がみられた。

4. 鋳造床粘膜面表層の走査電子顕微鏡観察では, コー
ティング試料においてコーティング材のジルコニアが焼き 付いた像が認められた。

5. 鋳造床粘膜面表層の硬さは, TAIVEST では両試 料間に差は認められなかった. T-INVEST C \& B では表 層 $30 \mu \mathrm{m}$ でコントロール試料のほうがやや大きい值を示 したが，以後の樑さでは両試料間に差は認められなかっ た.

6. 鋳造床粘膜面表層の金属組織は，コーティング試料 では明確なチル層はほとんど認められなかった。一方，コ ントロール試料には粘膜面表面からチル層, 柱状晶帯の順 に存在した。

7. 鋳造床粘膜面表層の元素分析において, コントロー ル試料では埋没材成分である $\mathrm{Si}, \mathrm{P}$ が存在する反応層が 認められた。一方，コーティング試料では，粘膜面表面に $\mathrm{Zr}$ が存在するものの, 不純物元素が存在する反応層は減 少していた。

以上の結果から，リン酸塩系埋没材を用いても耐火模型 表層にコーティング処理を施すことによって, 純チタン鋳 造床粘膜面表層に生じる反応層の改善が可能であることが 示唆された。

稿を終わるにあたりここ助言とご鞭撻をいただいた大成歯科工業 (株) 久保文信社長, 大阪大学接合科学研究所の先生方に深謝いたしま す.

なお, 本研究は大阪大学接合科学研究所共同利用によって行った。 本論文の要旨は第 99 回日本補経歯科学会学術大会 (1998 年 11 月 28 日, 仙台)に扔て発表した.

\section{文献}

1）三浦維四，井田一夫編. チタンの歯科利用 163-212, 東京：クイ ンテッセンス出版, 1988.

2）宮崎 隆.チタン鋳造はプレシャスメタルの精密鋳造を追い越 すことができるのか. 歯科技工 $18: 904-909,1990$.

3）都賀谷紀宏. チタン鋳造一私たちの取り組み方. 歯科技工 18 : 910-913, 1990.

4）奥野 攻.チタンの合金化とチタン鋳造機. 歯科技エ $18: 914$ 917, 1990.

5）奥野禮一、チタン鋳造システムの開発. 歯科技工 18:918-921, 1990.

6）新谷明喜. クラウン・ブリッジにおけるチタン鋳造の現状. 歯 科技工 $18: 922-925,1990$.

7）小正 裕, 中村茂幸, 根住正博ほか. 熱膨張抑制埋没材を用い たチタン鋳造一第 2 報 練和液が表面反応層に与える影響一。 補綴誌 $38 ： 303-314,1994$.

8）中村茂幸，小正 裕. 熱膨張抑制埋没材を用いたチタン鋳造一 第 3 報 大粒子コロイダルシリカを練和液として用いた場 合一. 補緅誌 $38: 753-765,1994$.

9) Komasa $Y$, Moriguchi A, Asai M et al. Effect of impression material on surface reactive layer when casting pure tita- 
nium in phosphate investment. J Osaka Dent Univ 32(2) : 47$57,1998$.

10）土居 寿, 米山隆之, 小竹雅人ほか. リン酸塩系埋没材を用い たチタン鋳造体表層の耐蝕性の検討. 歯材器 $11: 672-678$, 1992.

11）土居 寿, 米山隆之, 小竹雅人ほか. チ夕ン鋳造体表面反応層 の機械的性質に及涩す影響. 歯材器 $11: 817-822,1992$.

12）大川成剛, 渡辺孝一, 宮川修ほか. 市販チタン用埋没材と鋳 造体の表層に形成される反応層および鋳造体の機械的性質につ いて. 歯産学誌 6(6)：55-64, 1993.

13）亘理文夫，西村文夫，福本良平ほか. ジルコニア基埋没材の基 碟的研究. 歯材器 $6: 212-217,1987$.

14）亘理文夫，西村文夫，野本 直.チタンと酸化物耐熱間の高温 反応性に関する研究. 蒾材器 $7: 290-301,1988$.

15) Miyakawa $\mathrm{O}$, Watanabe $\mathrm{K}$, Okawa $\mathrm{S}$ et al. Layered structure of cast titanium surface. Dent Mater J 8(2) : 175-185, 1989.

16）橋本弘一，黒岩昭弘，和田賢一ほか. チ夕ン鋳造体表層の反応 生成物について. 歯材器 $11: 603-614,1992$.

17) Oda $Y$, Kudoh $Y$, Kawada $E$ et al. Surface reaction between titanium castings and investments. Bull Tokyo dent Coll
37 (3) : 129-136, 1996.

18）三村博史，宮川行男. チタン鋳造体の雨気化学的腐食挙動 第 2 報 内層部における研磨仕上処理の影響. 菌材器 $15: 296-$ $305,1996$.

19）宮崎 隆, 宮地俊幸. チタンの歯科鋳造について一鉡型材一. 歯科ジャーナル $30: 371-377,1989$.

20）高橋純造. チタン鋳造用鋳型材の研究開発の動向. QDT 16： 328-330, 1991.

21）金谷 貢，野村修一，石岡 靖ほか，窒化物系セラミックスの 歯科鋳造への応用一第 3 報 石高系外埋没材を用いた場合の Co - Cr 合金に対するコーティング材としての可能性. 補緅誌 34 ： 1235-1246, 1990.

22）宮川修，渡辺孝一，大川成剛ほか。巻き込まれた埋没材との 反応によってできるチタン鋳造体の内部欠陥. 歯材器 $10 ： 393-$ 403, 1991.

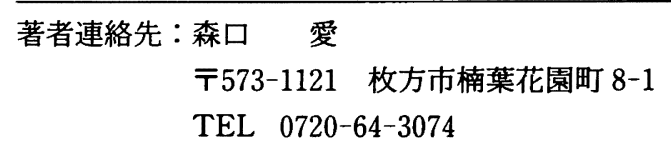

